\title{
Efficacy of Eosin Dye Removal by Peanut Shell Agrowaste Adsorbent
}

\author{
Parichat Srisamai ${ }^{1,2}$ \\ https://orcid.org/0000-0003-4199-5203 \\ Prakaipet Pankaew ${ }^{1}$ \\ https://orcid.org/0000-0002-4002-9276
}

\section{Poonnawis Sudtikoonaseth ${ }^{2}$ \\ https://orcid.org/0000-0001-9517-1942}

\author{
Niwat Kangwanrangsan ${ }^{1}$ \\ https://orcid.org/0000-0001-6090-6689 \\ Siriluck lamtham $3,4,5$ \\ https://orcid.org/0000-0003-1592-1075
}

\author{
Wannee Jiraungkoorskul ${ }^{1^{*}}$ \\ https://orcid.org/0000-0002-3070-280X
}

\begin{abstract}
${ }^{1}$ Mahidol University, Faculty of Science, Department of Pathobiology, Bangkok, Thailand; ${ }^{2}$ Ministry of Public Health, Institute of Dermatology, Department of Dermatopathology, Bangkok, Thailand; ${ }^{3}$ Kasetsart University, Institute for Advanced Studies, Center for Advanced Studies in Tropical Natural Resources, Bangkok, Thailand; "Kasetsart University Kamphaeng Saen Campus, Faculty of Liberal Arts and Science, Department of Science, Program of Bioproduct Sciences, Nakhon Pathom, Thailand; ${ }^{5}$ Kasetsart University Kamphaeng Saen Campus, Laboratory of Genetics, Nakhon Pathom, Thailand.
\end{abstract}

Editor-in-Chief: Alexandre Rasi Aoki

Associate Editor: Ivo Mottin Demiate

Received: 2020.11.24; Accepted: 2021.05.19.

${ }^{*}$ Correspondence: wannee.jir@mahidol.ac.th; Tel.: +66 22015550 (W.J.).

\section{HIGHLIGHTS}

- Peanut shell waste is an alternative adsorbent for the removal dyes.

- Ultrastructural visualization of peanut shell is the fiber structure shell, multi-layers and many linkages among the fibers which could create to various pores with different sizes.

- The best eosin $Y$ removal percentage had $87.7 \%$ in $25 \mathrm{~g} \mathrm{~L}^{-1}$ of peanut shell at 30 minute.

Abstract: Peanut shell (PS) which is an excessive waste-product from agricultural processes, it can be recycled to a natural adsorbent for example it uses as removal dyes. Synthetic dye effluent without improperly discharged from industries to the river cause wastewater and damage to living organisms, especially, anionic dyes are difficult removed by conventional treatments such as biological, chemical, oxidation, and physicalfiltration. However, an adsorption treatment is widely used for decolorization of dyes and give the best results for removal of various types of dissolved coloring materials. This research was used Eosin $Y$ (EO) for the anionic model of dyeing wastewater and used PS for agrowaste adsorbent. The purpose of this study was investigated the efficiency adsorption of EO removal by PS. This efficiency adsorption was measured by different PS dosages, contact times, adsorbate concentration and equilibrium data. The results can be concluded that the PS had the efficiency adsorption of EO removal due to the equilibrium adsorption capacity $\left(q_{\mathrm{e}}\right)$ and the highest dose of PS were balanced to adsorption of dye. The highest EO removal percentage was found in $87.7 \%$, the qe was $0.351 \mathrm{mg} \mathrm{g}^{-1}$ and can adsorb from $10 \mathrm{mg} \mathrm{L}^{-1}$ to $1.23 \mathrm{mg} \mathrm{L}^{-1}$ in $25 \mathrm{~g} \mathrm{~L}^{-1}$ of PS dose at 30 minutes. In addition, the PS structure was found in multi-layer and many porous which is suitable for adsorbent. The morphological examination of PS was shown before and after adsorption that not changed. Therefore, PS might be an alternative choice for removal dye, and be used for the recycle adsorbent agrowaste as a commercial product for adding their values. 
Keywords: Adsorbent; Adsorption; Agrowaste; Arachis hypogaea; Eosin Y; Peanut shell.

\section{INTRODUCTION}

The dyeing wastewater causes a big problem water pollution in worldwide. It is produced by many industries such as cosmetic, medical laboratory, paper, leather tanning and plastic [1], which textile manufacturing alone is the most release dyes into river due to it is not completely disposed of dyes during water treatment. It has been reported that the textile industry has the global annual production of dyes amounts to a million metric tons such as from the People's Republic of China and India, they are the largest textile industries in Asia [2]. The most of dye industries are wildly used synthetic dyes to present color to their products. Dyes are chemical compounds, and can be classified into three types according to the nuclear structures i.e., anionic dyes (acidic and reactive), non-ionic dyes (disperse), and cationic dyes (basic) [3]. Mostly, these dyes are dangerous to human health especially the workers who exposed in the work places such as lung eye, mouth and skin irritation [4]. They also have affected on living organisms and ecosystem such as disruption of plant growth or the heavy metal complex dyes are suffering the gills of fishes. However, the advantages of synthetic dyes, they have a wide range of colors for their products. In this study, Eosin $Y$ (EO) was used for a model as anionic dye. EO is potentially problematic compounds from aqueous solution which can lead to wastewater on during several processes such as histological staining. This dye causes toxic, carcinogenic effects on aquatic biota including plants and animals and also humans. According to Sharma and coauthors [5] had reported EO may cause severe skin and eye irritation and while on ingestion that had also effected into vital organs. The inhalation of the dye can reduce the pulmonary gas exchange capacity [6] and the metabolites are also highly toxic and carcinogenic substances [7]. Therefore, it should be necessary to remove EO from aqueous solution.

Technology of wastewater treatment can be divided into three categories based on characteristic and structural properties $[8,9]$. First, it is the biological treatment that used microorganism such as bacteria, nematodes, or small organisms to break down organic wastes. Second, it is the chemical treatment that used chlorine, ozone, hydrogen peroxide or etc. Last, it is the physical treatment that used sedimentation, flotation, filtration, separation or adsorption [10]. Among these processes, the adsorption is a popular treatment that used for supporting any treatments to dye effluent manufacturing [11-14]. The dye effluents generated from rubber, plastic, leather and textile processing plants contain different types of synthetic dyes, such as malachite green, methyl violet, azure dye, indigo carmine, methylene blue, eosin and rhodamine [15]. This adsorption process will separate the substances of solution or contaminants, and bind to outer surfaces of solid materials that call adsorbent [16]. Some of the low cost adsorbent used for adsorption are obtained from the domestic, agricultural or industrial sources [17,18]. Our research group is focusing in the natural adsorbents from agricultural waste such as activated carbon, peanut shell, egg shell, banana peel and orange peel. Activated carbon can be produced from wood or coconut which it has been reported that can adsorbed methylene blue from aqueous solution [9]. Pumice and walnut activated carbon can removed reactive black from aqueous solution [12]. The peanut shell (PS) is eco-friendly environment that used in separation of oil and water [19]. Aloe vera adsorbent was removal of hazardous crystal violet [20]. Egg shell is also natural adsorbent for removal of fluoride from aqueous solution [21]. Banana peel is used to adsorption of rhodamine dye and heavy metal from aqueous solution [22]. Moreover, orange peel is also used for adsorption rhodamine dye from aqueous solution [17]. The commercial activated carbon is a popular absorbent for the elimination of variety of dyes [23]. However, it has high costly and can lead to global warming from burning process. The dust from activated carbon can risk to respiratory system. More interesting, PS is a numerous solid waste from agriculture after it is harvested in farm. PS has high volume and low density, therefore, it may be an alternative choice for color removal [24]. In addition, it is inexpensive, easy find in location, and include for recycling of the agricultural waste or agro-waste and want to more adding values [25].

The aim of this study was to use the agrowaste peanut shell as a natural adsorbent and investigated the efficiency adsorption of eosin $\mathrm{Y}$ from aqueous solutions. The parameters of adsorption and equilibrium data were studied via various contact times, adsorbent dosages and adsorbate concentrations. In addition, the morphological examination of peanut shell was observed by Field Emission Scanning Electron Microscopes (FE-SEM). 


\section{MATERIAL AND METHODS}

\section{Adsorbent preparation}

Peanut was bought from a local market in Bangkok, Thailand. The preparation of peanut shell agrowaste methodology was modified from Arunlertaree and coauthors [26] and Massie and coauthors [27]. First, the peanut was washed thoroughly with tap water to minimize its chromaticity and remove any dirty. Next, it was boiled in $100^{\circ} \mathrm{C}$ for $30 \mathrm{~min}$, then removed the shell. The adsorbent as PS was dried in the hot air oven at $65^{\circ} \mathrm{C}$ for 24 hours. The dried PS was grinded by blender machine to fine powder, then PS powder was sieved through to $2 \mathrm{~mm}$ diameter and stored in glass container.

\section{Adsorbate preparation}

Eosin $\mathrm{Y}(\mathrm{EO})$, C20H6Br4Na2O5 (Sigma-Aldrich, USA) was used as model for anionic dye in this study. The EO was molecular weight of $647.89052 \mathrm{~g} \mathrm{~mol}^{-1}$ [28-30]. The stock dye solution was prepared by dissolving $0.1 \mathrm{~g}$ of dye powder in $1.0 \mathrm{~L}$ of distilled water to give a concentration of $100 \mathrm{mg} \mathrm{L}^{-1}$ and diluting when necessary. The $5 \mathrm{ml}$ of $10 \mathrm{mg} \mathrm{L}^{-1}$ of dye solution was measured for optical density using UV-visible spectrophotometer wavelength from 400 to $800 \mathrm{~nm}$ for range finding and the definitive finding wavelength. The test was done triplicate. The maximal wavelength $\left(\lambda_{\max }\right)$ was recorded and used in this study. The 0,2 , 4, 6, 8 and $10 \mathrm{mg} \mathrm{L}^{-1}$ of EO were measured optical density at maximum wavelength for the standard curve.

\section{Ultrastructural visualization of adsorbent}

Morphological examination of PS was performed by using Field Emission Scanning Electron Microscopes (SU8010 FE-SEM, Hitachi, Japan). The PS was mounted on a circular disc-like structure or stub at size 2 inches. Specific carbon tape was used to attach with PS to the surface of the stub, and was coated on platinum-palladium alloy (Pt-Pd) by using ion sputter machine (E102, Hitachi, Japan). The ion sputter operated at 0.1 Pascal Torr, $20 \mathrm{~mA}$ for 2.30 minute. The microscopic analysis was operated at $10 \mathrm{kV}$ and $10 \mu \mathrm{A}$. Image analysis was used Hitachi SU8000 series SEM software to determine the size of the adsorbent.

\section{Adsorption of peanut shell}

The adsorbent dosages of dried PS powder were 5, 25, and $50 \mathrm{~g} \mathrm{~L}^{-1}$, and the adsorbate EO dose was fixed at $10 \mathrm{mg} \mathrm{L}^{-1}$. They were shaken at speed $140 \mathrm{rpm}$ by Orbit Shaker (VRN-480 Gemmy, Taiwan) for 30, 60, 90 and 120 minutes for the contact time experiment in room temperature. After shaking, the absorptive removal of dyes were separated by Whatman ${ }^{\circledR}$ Grade 1 (Merck, Thailand). The each of supernatant was measured by $\mathrm{pH}$ meter (Oakton PH 700 Benchtop, USA), and was measured the optical density at the maximum wavelength. The optical density was converted to concentration from the standard curve. The PS power before and after adsorption experiments were dried at $65^{\circ} \mathrm{C}$ in hot air oven (WiseCube® Fuzzy Control System, Germany) overnight and were collected for the morphological examination by FE-SEM. The amount of equilibrium adsorption, $\mathrm{q}_{\mathrm{e}}\left(\mathrm{mg} \mathrm{g}^{-1}\right)$, was calculated using the following Equation (1):

$$
q_{e}=\frac{c_{i}-c_{e}}{w} v
$$

Where $\mathrm{C}_{\mathrm{i}}$ and $\mathrm{C}_{\mathrm{e}}\left(\mathrm{mg} \mathrm{L}^{-1}\right)$ were the liquid-phase concentrations of $\mathrm{EO}$ initially and at equilibrium, $V(\mathrm{~L})$ was the volume of EO solution, and W (g) was the mass of the dried PS adsorbent.

The percentage removal of EO was calculated using the Equation (2):

$$
\% \text { Dry removal }=\frac{c_{i}-c_{e}}{c_{i}} 100
$$

Where $\mathrm{C}_{\mathrm{i}}$ and $\mathrm{Ce}\left(\mathrm{mg} \mathrm{L}^{-1}\right)$ were the initial and equilibrium concentrations of the EO. 


\section{RESULTS AND DISCUSSION}

\section{Characterization of peanut shell}

The morphological characterization of PS before adsorption of dye was shown in Figure 1 and after adsorption of dye was shown in Figure 2. PS had the fiber structure shell, multi-layers and many linkages among the fibers which could create to various pores with different sizes. The comparison of PS before and after adsorption for removal EO, both of fiber structures were not changed, they still had many pores. However, the PS after absorptive dye was shown the dye that adhered with the fiber structure and pores. Therefore, the characterization of PS was suitable for bio-adsorbent for EO or any dyes in an anionic group. This result was in agreement with the previous reports. Mojsov and coauthors [31] analysed the morphology of powder peanut hull and used it to adsorb Reactive Black 5, an anionic dye. Xu and coauthors [32] observed the morphology of the activated carbon from PS, and reported that it also had the fiber structure, poly pores and used for removal the organic pollutants from soil eluent. Garga and coauthors [33] also studied the surface morphology of PS and reported that it was showed the porous structure and high amount of cellulose and used for removal Acid Yellow 36, an anionic dye.

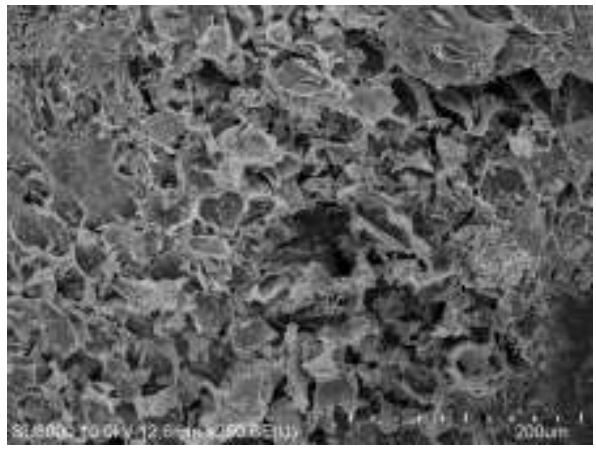

(a)

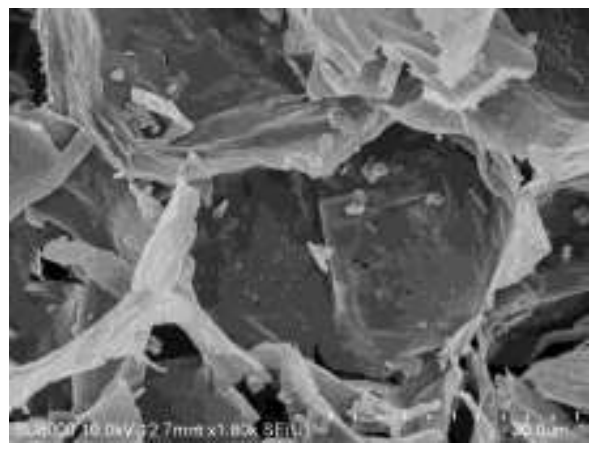

(b)

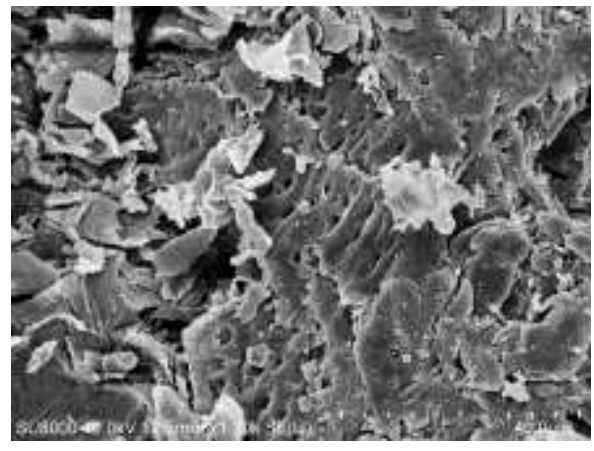

(c)

Figure 1. FE-SEM Images of PS before adsorption for EO: (a) PS wasn't grind at High power $12.6 \mathrm{~mm} \times 250 \mathrm{SE}(\mathrm{U})$, size $200 \mu \mathrm{m}$; (b) PS wasn't grind at High power $12.7 \mathrm{~mm} \times 1.80 \mathrm{k} \mathrm{SE}(\mathrm{U})$, size $30.00 \mu \mathrm{m}$; (c) PS was grind at High power $12.5 \mathrm{~mm} \times 1.30 \mathrm{k} \mathrm{SE}(\mathrm{U})$, size $40.0 \mu \mathrm{m}$.

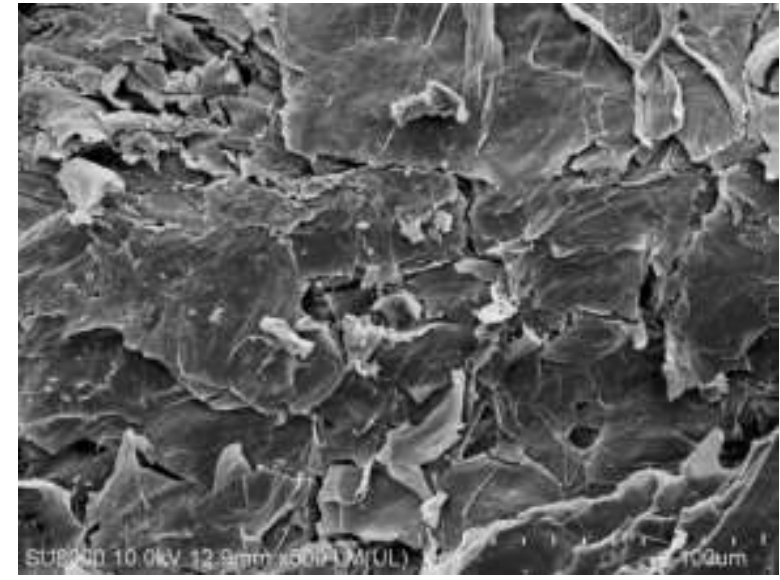

(a)

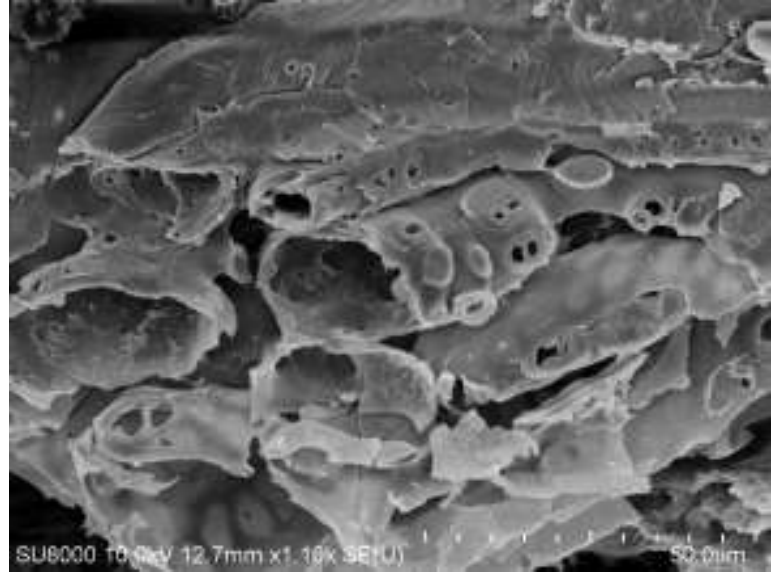

(b) 


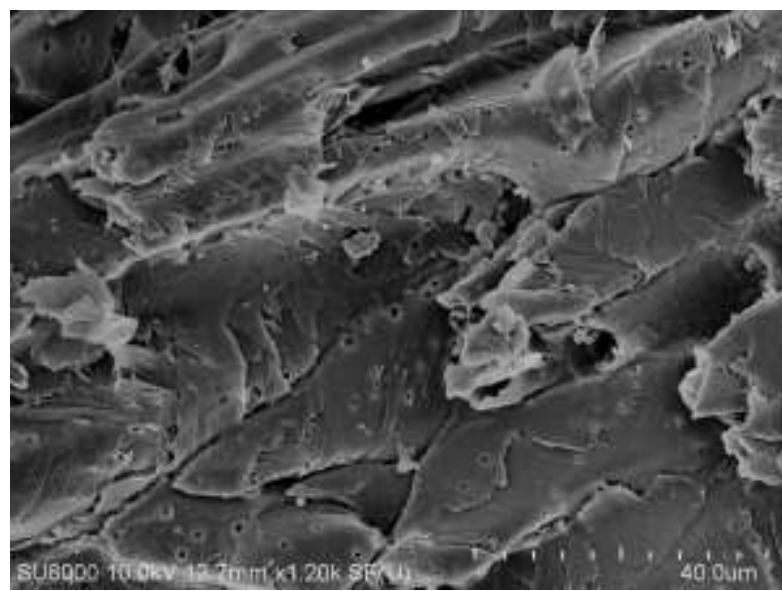

(c)

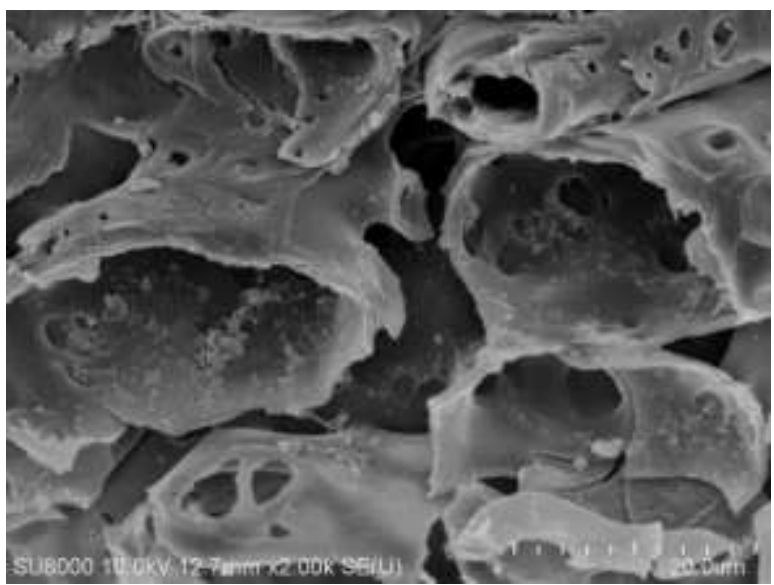

(d)

Figure 2. FE-SEM Images of PS powder after adsorption for EO: (a) Low power $12.9 \mathrm{~mm} \times 500 \mathrm{LM}(\mathrm{UL})$, size $100 \mu \mathrm{m}$; (b) High power $12.7 \mathrm{~mm} \times 1.10 \mathrm{k} \mathrm{SE}(\mathrm{U})$, size $50.00 \mu \mathrm{m}$; (c) High power $12.7 \mathrm{~mm} \times 1.20 \mathrm{k} \mathrm{SE}(\mathrm{U})$, size $40.0 \mu \mathrm{m}$; (d) High power $12.7 \mathrm{~mm} \times 2.00 \mathrm{k} \mathrm{SE}(\mathrm{U})$, size $20.0 \mu \mathrm{m}$.

\section{Preparation of standard curve for eosin $Y$ solution}

The EO solutions in $0,2,4,6,8$ and $10 \mathrm{mg} \mathrm{L}^{-1}$, were measured by optical density at maximum wavelength $523 \mathrm{~nm}$, which had the average optical density at $0,0.106,0.200,0.289,0.388$ and 0.477 , respectively. The $R$-squared $\left(R^{2}\right)$ of this standard curve was 0.9988 and $y=0.0483 x$. The graph of standard curve was shown in Figure 3. According to y value of standard curve can be calculated the concentration of absorptive removal dye [34].

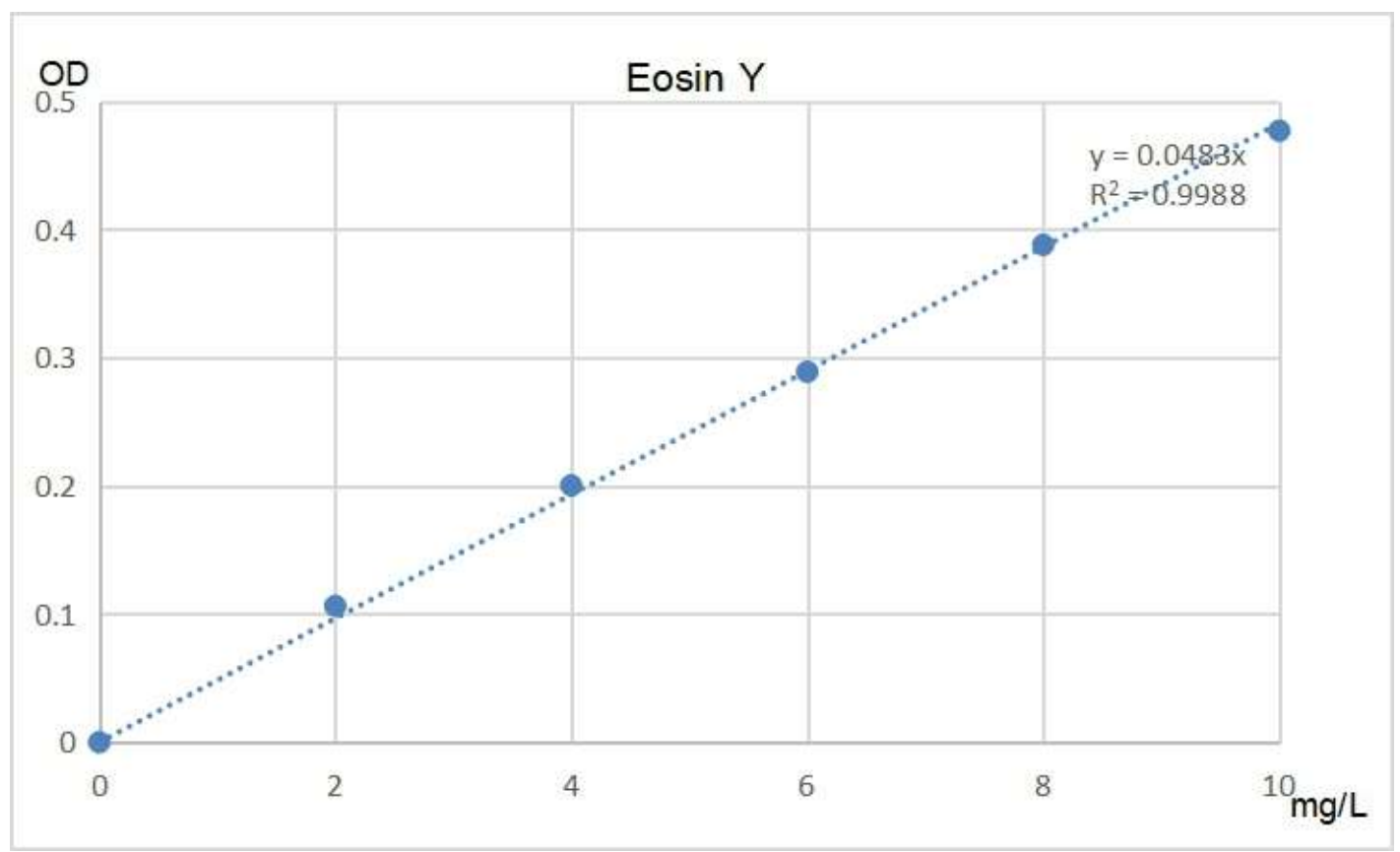

Figure 3. Graph of standard curve in various EO solutions at $\mathrm{OD}_{523}$.

\section{Efficiency of peanut shell for removal eosin Y solution}

\section{Effect of adsorbent dosage}

The effect of PS adsorbent dose for the removal of $100 \mathrm{ml}$ of $10 \mathrm{mg} \mathrm{L}^{-1} \mathrm{EO}$ was studied by variation in the dose of PS from 5, 25 and $50 \mathrm{~g} \mathrm{~L}^{-1}$. In addition, the contact times for absorbed dye were varied from 30 , 60,90 and 120 minutes. The results were shown in Figure 4. The concentration of absorptive removal dye was calculated by value of y from standard curve on eosin solutions at $\mathrm{OD}_{523}$. More addition, the $5 \mathrm{~g} \mathrm{~L}^{-1}$ of 
PS can adsorb from the $10 \mathrm{mg} \mathrm{L}^{-1} \mathrm{EO}$ to $1.82,1.68,1.41$ and $1.41 \mathrm{mg} \mathrm{L}^{-1} \mathrm{EO}$ at times $30,60,90$ and 120 minutes, respectively. The $25 \mathrm{~g} \mathrm{~L}^{-1}$ of PS can adsorb from the $10 \mathrm{mg} \mathrm{L}^{-1} \mathrm{EO}$ to $1.23,1.70,1.70$ and $1.73 \mathrm{mg}$ $\mathrm{L}^{-1} \mathrm{EO}$ at times $30,60,90$ and 120 minutes, respectively. Finally, the $50 \mathrm{~g} \mathrm{~L}^{-1}$ of PS can adsorb from the 10 $\mathrm{mg} \mathrm{L}^{-1} \mathrm{EO}$ to $1.41,2.05,2.51$ and $2.39 \mathrm{mg} \mathrm{L}^{-1} \mathrm{EO}$ at times $30,60,90$ and 120 minutes, respectively. These results were showed that the efficacy of PS was time and dose dependence.

\section{Concentration of absorptive removal EO}

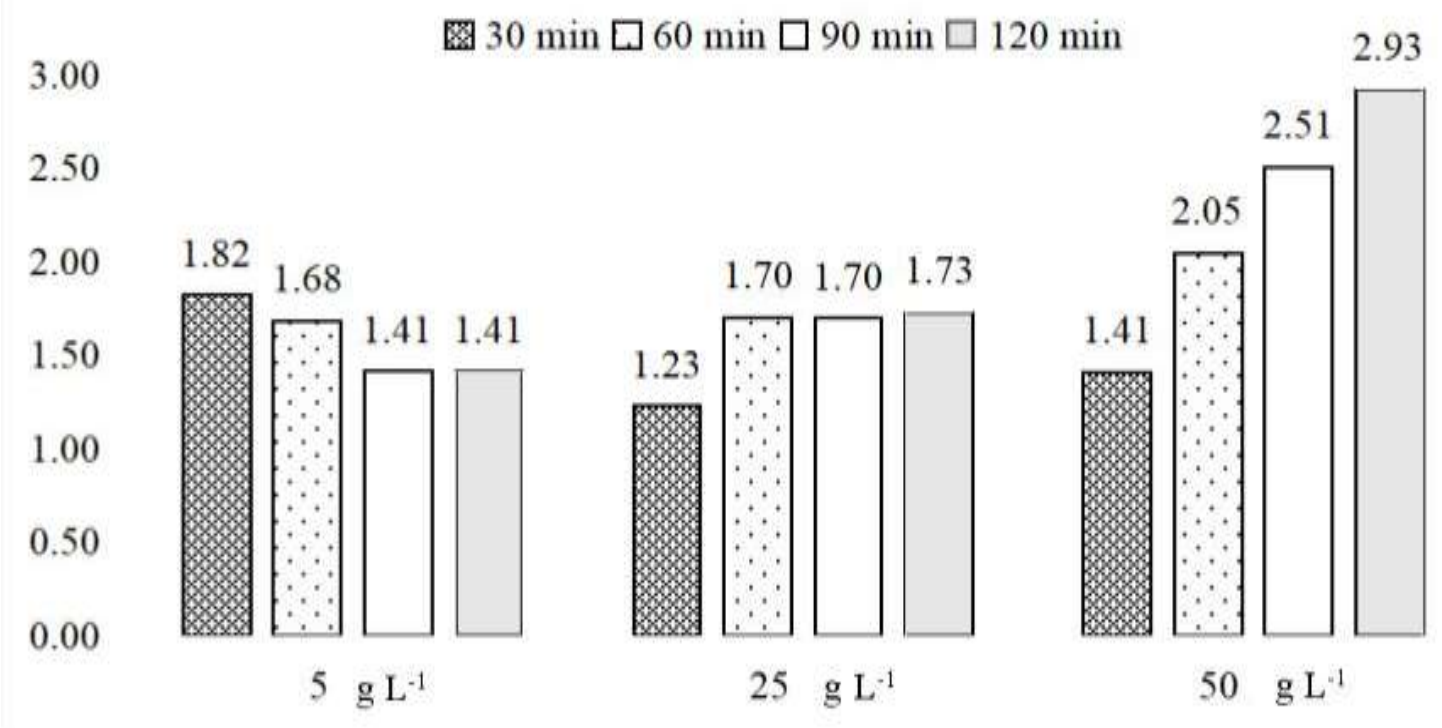

Figure 4. Graph of concentration of absorptive removal EO from aqueous solution.

However, at 90 to 120 minutes, the PS were invariable for adsorption. The present results were in agreement with the previous reports. Salleh and coauthors [35] had reviewed the effect of cationic and anionic dye adsorption by agricultural solid wastes for the examples peanut shell, rice husk and activated carbon biochar. The concentration of dyes such as methylene blue, brilliant cresyl blue, neutral red, congo red and reactive black 5 were decreased in low adsorbent dose at the highest time. However, when increased dose of adsorbent, the concentrations of dyes were rapid decreased in lower time [35]. In addition, Sattar and coauthors [36] evaluated the efficiency of peanut shell and peanut shell biochar for removal of arsenic from water, the results of the concentration of arsenic metal were decreased from $5 \mathrm{mg} \mathrm{L}^{-1}$ in various adsorbent doses at 2 hour which was associated with equilibrium adsorption capacity that increased adsorbent dose can lead to reduced concentration of dye and reached to equilibrium adsorption at lower time. Moreover, the peanut shell adsorbent was used to removal Acid Yellow 36, at initial dose $100 \mathrm{mg} \mathrm{L}^{-1}$ with various adsorbent doses 2 to $6 \mathrm{~g} \mathrm{~L}^{-1}$ at contact times 20 to $160 \mathrm{~min}$ [33]. The $\mathrm{pH}$ values of EO were measured in before $(\mathrm{pH}=$ 4.91) and after adsorption, the results were shown in Figure 5. The $\mathrm{pH}$ values of $\mathrm{EO}$ after shaking with the 5 $\mathrm{g} \mathrm{L}^{-1}$ of PS at times $30,60,90$ and 120 minutes were 4.09, 4.00, 3.93 and 3.90, respectively. Next, the pH values of EO after shaking with the $25 \mathrm{~g} \mathrm{~L}^{-1}$ of PS at times 30, 60, 90 and 120 minutes were 3.57, 3.53, 3.51 and 3.49, respectively. Finally, the $\mathrm{pH}$ values of $\mathrm{EO}$ after shaking with the $50 \mathrm{~g} \mathrm{~L}^{-1}$ of PS at times $30,60,90$ and 120 minutes were $3.37,3.36,3.36$ and 3.33 , respectively. 


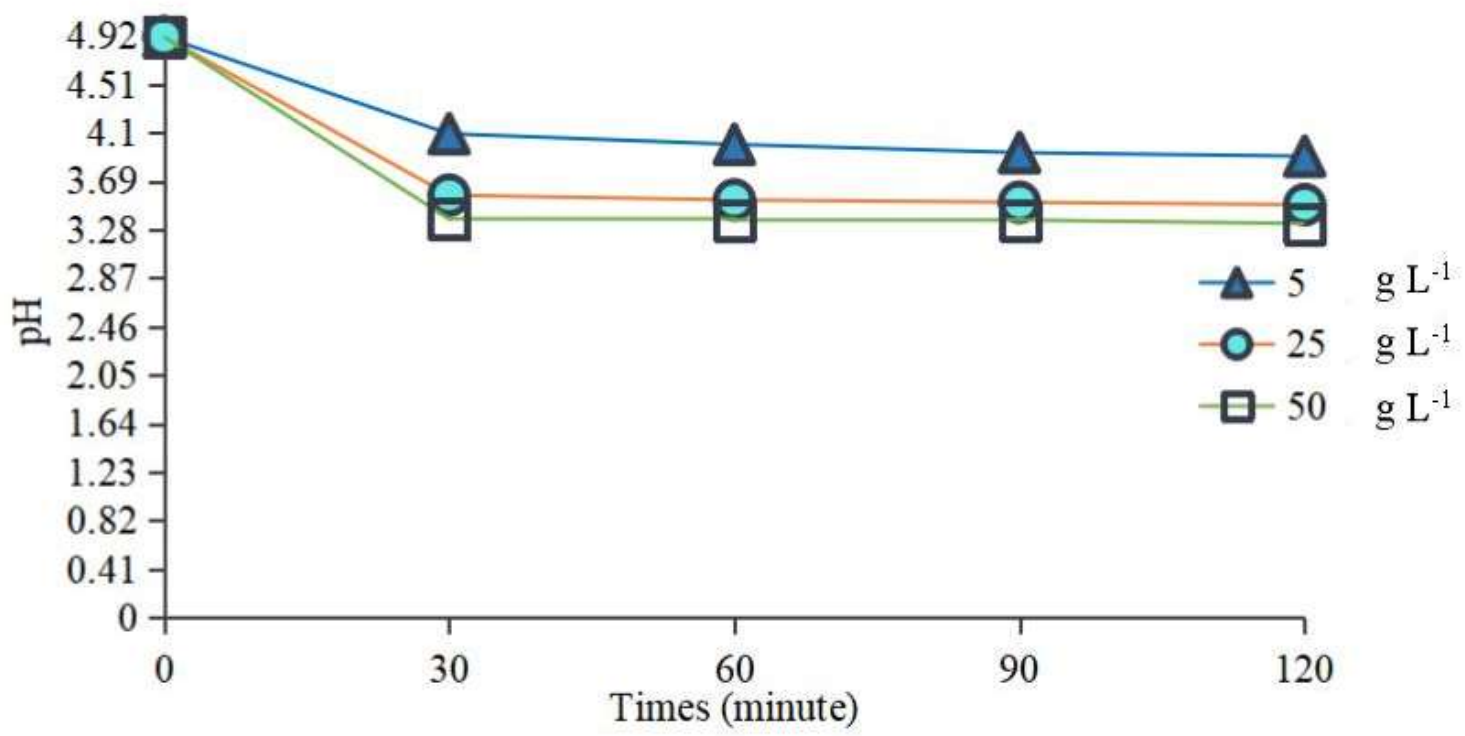

Figure 5. $\mathrm{pH}$ values after adsorption of EO by PS

The result of $\mathrm{pH}$ values were indicated to the adsorptive removal of EO from aqueous solution, there were increased acid in all of adsorbent doses when compared with only dye without adsorption. It might be the ferment of peanut shell that made acid during adsorption for removal dye, and the EO is an acid dye. According to [37,38], the $\mathrm{pH}$ affects the substance surface binding-sites and chemistry of aqueous solutions, and including of the charge on adsorbent surface with the degree of ionization of the dye. The $\mathrm{pH}$ of media can change the structure of dye, it gets protonated form in the acidic medium and deprotonated form at higher $\mathrm{pH}$. From the other previous studies, Boumchita and coauthors [23] were adjusted the ranges of $\mathrm{pH}$ values of Eriochrome Black T, an anionic dye, they found that the percentage removal of the dye decreased from $99 \%$ to $10 \%$ as the $\mathrm{pH}$ of the solution increased from 2 to 12 . Witek-Krowiak and coauthors [39] reported that the $\mathrm{pH}$ decreased when the concentrations of protons were increased and competition in binding the active sites on the surface of the biosorbent, by the $\mathrm{H}^{+}$and metal ions. Protonated active sites were incapable of binding the bind metal ions, leading to free ions remaining in the solution [39]. It might be related to the result of $\mathrm{pH}$ value in the present study that shown protonated form, can change the structure of $\mathrm{EO}$. As the $\mathrm{pH}$ decreased, the competing effect of $\mathrm{H}+$ ions were increased and the functional groups carrying positive charges were exposed and lead to electrostatic attraction between dye anion and adsorbent [40].

\section{Effect of contact time}

The effect of contact times on the removal of $100 \mathrm{ml}$ of $10 \mathrm{mg} \mathrm{L}^{-1} \mathrm{EO}$ by the PS adsorbent were evaluated for various times: 30, 60, 90 and 120 minutes. The amount of equilibrium adsorption, $\mathrm{q}_{\mathrm{e}}\left(\mathrm{mg} \mathrm{g}^{-1}\right)$, was calculated using the Formula 1. Figure 6 was shown the $\mathrm{q}_{\mathrm{e}}$ after shaking with the $5 \mathrm{~g} \mathrm{~L}^{-1}$ of PS at times 30 , 60,90 and 120 minutes were $1.636,1.664,1.718$ and $1.718 \mathrm{mg} \mathrm{g}^{-1}$, respectively. The $\mathrm{q}_{\mathrm{e}}$ after shaking with the $25 \mathrm{~g} \mathrm{~L}^{-1}$ of PS at times 30,60, 90 and 120 minutes were $0.351,0.332,0.332$ and $0.331 \mathrm{mg} \mathrm{g}^{-1}$, respectively. The $\mathrm{q}_{\mathrm{e}}$ after shaking with the $50 \mathrm{~g} \mathrm{~L}^{-1}$ of PS at times 30,60, 90 and 120 minutes were $0.172,0.159,0.150$ and $0.141 \mathrm{mg} \mathrm{g}^{-1}$, respectively. The equilibrium dye uptake capacity $\left(\mathrm{q}_{\mathrm{e}}\right)$ was found to decrease in PS adsorbent ranging from 5,25 and $50 \mathrm{~g} \mathrm{~L}^{-1}$. The $5 \mathrm{~g} \mathrm{~L}^{-1}$ of PS was slower adsorption capacity in 30 to $60 \mathrm{~min}$, and was approached to equilibrium at $90 \mathrm{~min}$. While, the $25 \mathrm{~g} \mathrm{~L}^{-1}$ of PS was equilibrium adsorption capacity at $30 \mathrm{~min}$ and was decreased adsorption of dye from $60 \mathrm{~min}$ to $120 \mathrm{~min}$. Moreover, the equilibrium adsorption capacity of $50 \mathrm{~g} \mathrm{~L}^{-1}$ of PS was 30 min and slightly decreased adsorption of EO from 60 min to $120 \mathrm{~min}$. Therefore, the best equilibrium efficiency of adsorption for removal dye by peanut shell adsorbent was 30 min when adding to adsorbent dose. 


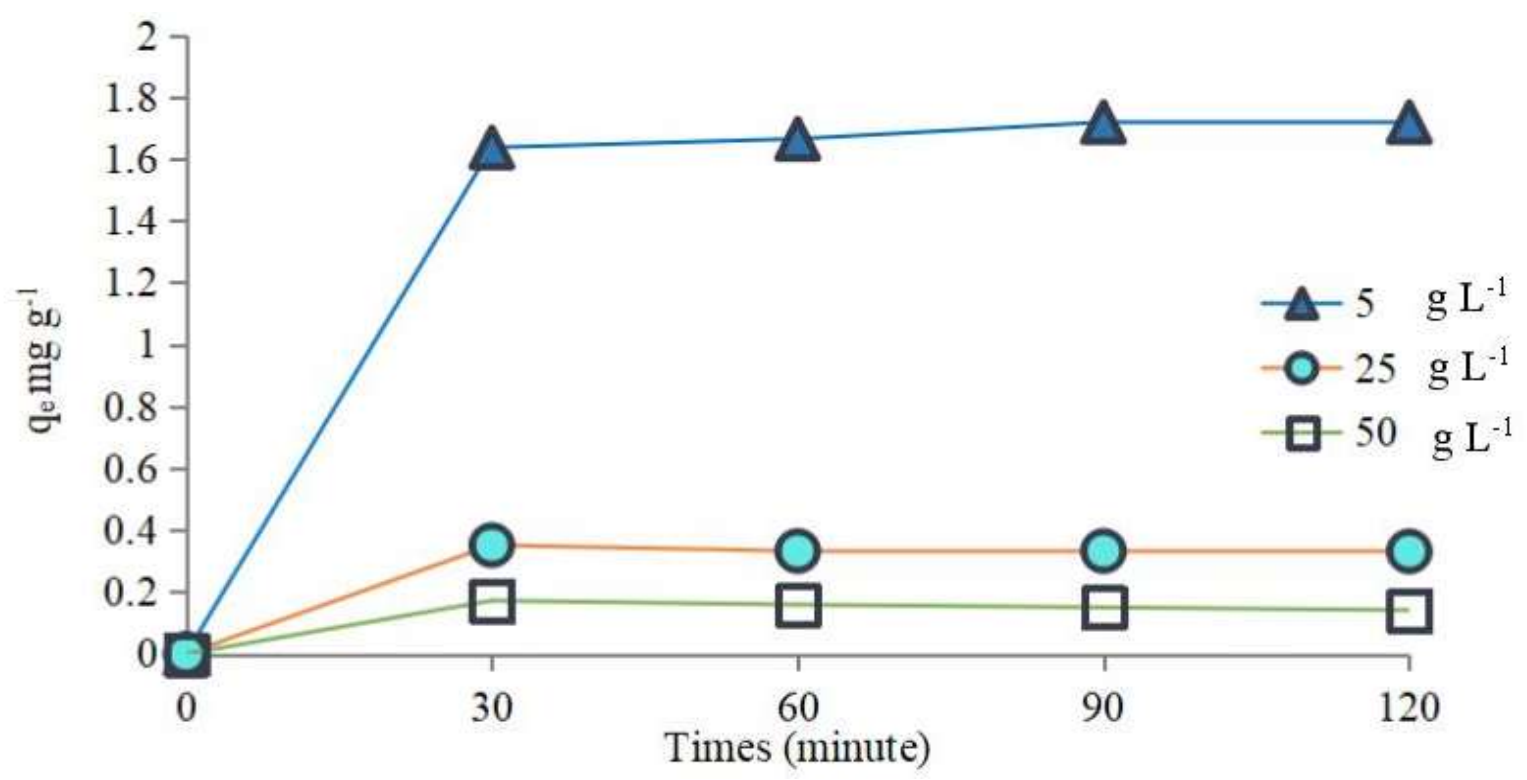

Figure 6. The amount of equilibrium adsorption, $\mathrm{qe}_{\mathrm{e}}\left(\mathrm{mg} \mathrm{g}^{-1}\right)$ at various times and different adsorbent doses.

The present results were in agreement with the previous reports. Villarreal and coauthors [41] studied the adsorption capacity of anionic dyes (AB25, AB74 and RB4 dyes) with natural adsorbents (peanut shell and pecan shell). The adsorption capacities $\left(\mathrm{q}_{\mathrm{e}}\right)$ were shown $3.2-8.5 \mathrm{mg} \mathrm{g}^{-1}$ with $20 \mathrm{mg} \mathrm{L}^{-1}$ initial dye concentrations and $10 \mathrm{~g} \mathrm{~L}^{-1}$ of natural adsorbent dose at various times 20-60 min. According to Gama and coauthors [42] had shown the adsorption capacities of PS with metals that were reduced with the increase in concentration levels of the adsorbent which were shown lower adsorbate/adsorbent ratio. Moreover, the effect equilibrium of adsorption was shown rate slowly increase to reach equilibrium in about $60 \mathrm{~min}$ of different concentration of Eriochrome Black T dye (50, 70, 90 and $\left.120 \mathrm{mg} \mathrm{L}^{-1}\right)$ with adding to adsorbent dose of PS (0.05 to $\left.2.00 \mathrm{~g} \mathrm{~L}^{-1}\right)$ [10]. In addition, Tahir and coauthors [43] reported the crystal violet (cation) dye was removed with peanut shell by these conditions: $0.1 \mathrm{~g}$ adsorbent doses, $50 \mathrm{mg} \mathrm{L}^{-1}$ dye initial concentration and 20-120 min contact times, which the equilibrium adsorption capacity was balanced for removal dye at the highest time.

\section{Percentage of removal eosin dye}

The results of percentage removal $(\% \mathrm{R})$ for EO were shown in Figure 7 . The \%R after shaking with the $5 \mathrm{~g} \mathrm{~L}^{-1}$ of PS at times 30,60, 90 and 120 minutes were $81.8 \%, 83.2 \%, 85.9 \%$ and $85.9 \%$, respectively. The \%R after shaking with the $25 \mathrm{~g} \mathrm{~L}^{-1}$ of PS at times $30,60,90$ and 120 minutes were $87.7 \%, 83.0 \%, 83.0 \%$ and $82.7 \%$, respectively. The \%R after shaking with the $50 \mathrm{~g} \mathrm{~L}^{-1}$ of PS at times 30, 60, 90 and 120 minutes were $85.9 \%, 79.5 \%, 74.9 \%$ and $70.7 \%$, respectively. The result was indicated the percentage of removal EO that shown the best adsorption in $25 \mathrm{~g} \mathrm{~L}^{-1}$ of PS. 


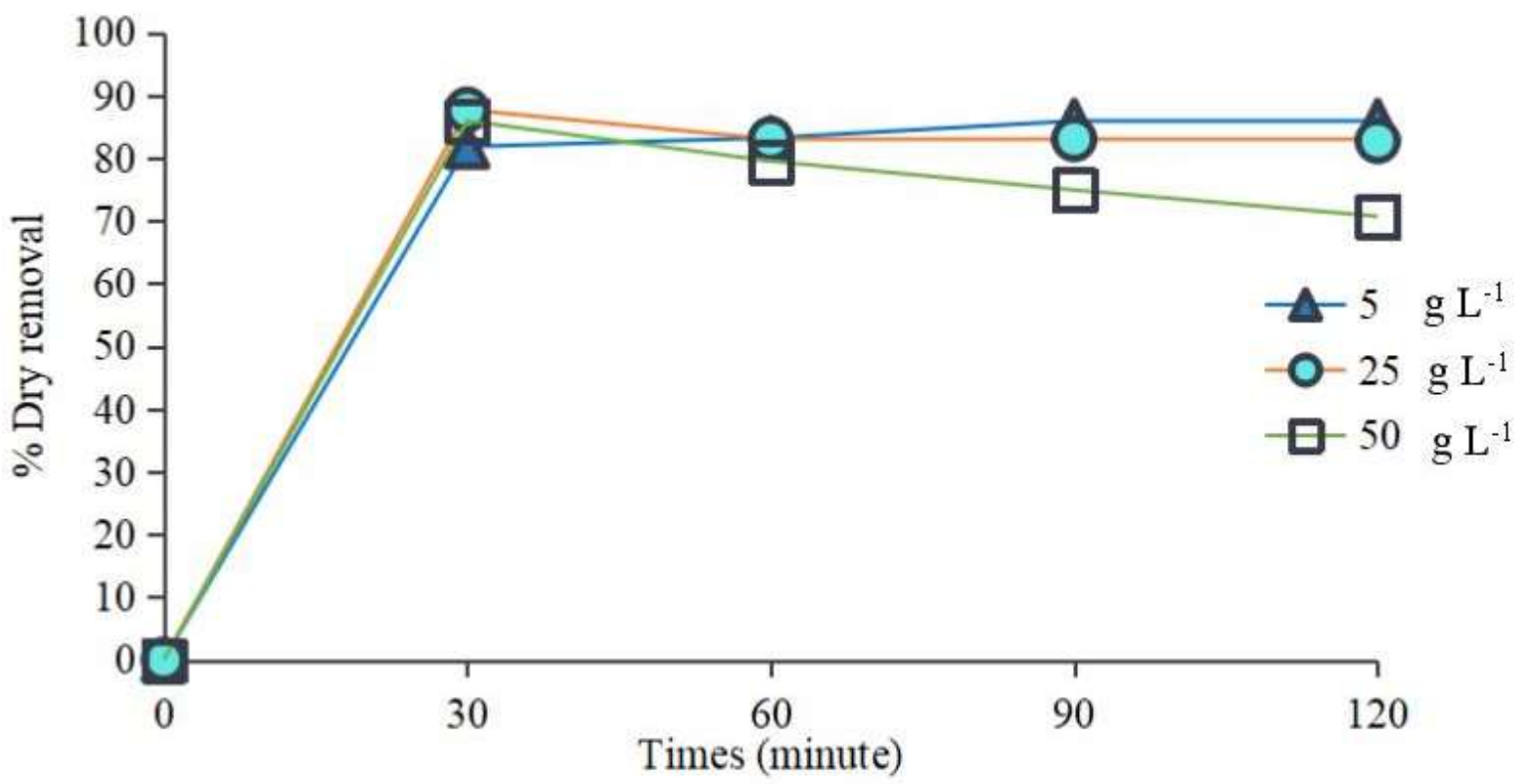

Figure 7. Percentage removal (\% R) for eosin dye.

The present results were in agreement with the previous reports. Boumchita and coauthors [23] evaluated the efficiency of PS adsorbent with Acid Yellow 36 dye. They reported that the removal of Acid Yellow 36 dye was shown the maximum efficiency at 30 min contact time with the percentage of removal was $50 \%$ with an adsorbent dose of $2 \mathrm{~g} \mathrm{~L}^{-1}$. Moreover, Garga and coauthors [33] analysed the effect of 50-120 $\mathrm{mg} \mathrm{L}^{-1}$ the initial concentration of Eriochrome Black $T$ and the fixed concentration at $2 \mathrm{~g} \mathrm{~L}^{-1}$ of peanut shell. The percentage of removal was decreased with the increase in the initial dye concentration.

\section{CONCLUSION}

The present study was concluded the efficiency of anionic dye (Eosin Y) adsorption onto dried peanut shell as an adsorbent. Due to the peanut shell is an ago-waste, it might be suitable for recyclable waste. The main finding such as the morphological of peanut shell which was found multi-layers of fiber structure. This structure has be created many porous and different sizes. So it is the great characteristic for the adsorptive process. Moreover, the parameters that were used for the efficiency evaluation such as different adsorbent doses, various contact times and initial dye concentration have also been importance. In addition, the Eosin $\mathrm{Y}$ is an acid dye, during the adsorption, the $\mathrm{pH}$ is more acid in the high dose and in the maximum contact time. Therefore, the PS might be a good alternative bio-sorbent, low cost and has the suitable structure for adhered with Eosin $Y$ dye which it might be depended on electron charge of anionic (negative) dye that bind with positive charge in peanut shell.

Acknowledgements: This research was supported by Department of Medicinal Service Fund (Academic Support), Ministry of Public Health, Thailand in Academic Year of 2018. We would like to thank the members of the Aquatic Toxicopathology Unit, Department of Pathobiology, Faculty of Science, Mahidol University, Thailand for their technical support in the laboratory.

Conflicts of Interest: The authors declare no conflict of interest. The funders had no role in the design of the study; in the collection, analyses, or interpretation of data; in the writing of the manuscript, or in the decision to publish the results.

\section{REFERENCES}

1. Mansour BH, Corroler D, Barillier D, Ghedira K, Chekir L, Mosrati R. Evaluation of genotoxicity and pro-oxidant effect of the azo dyes: Acids yellow 17, violet 7 and orange 52, and of their degradation products by Pseudomonas putida mt-2. Food Chem. Toxicol. 2007; 45(9): 1670-7.

2. Vasques AR, Ulson de Souza SMAG, Valle JAB, Ulson de Souza AA. Removal of dyes from the textile industry by adsorption in fixed bed columns: A sustainable process. Chem. Prod. Process Model. 2009; 4(4): 1-11.

3. Robinson T, McMullan G, Marchant R, Nigam P. Remediation of dyes in textile effluent: A critical review on current treatment technologies with a proposed alternative. Bioresour. Technol. 2001; 77(3): 247-55. 
4. Hassaan MA, Nemr AEl. Health and environmental impacts of dyes: Mini review. Am. J Environ. Sci. Eng. 2017;1(3):64-7.

5. Sharma S, Goyal RP, Chakravarty G, Sharma A. Toxicity of tomato red, a popular food dye blend on male albino mice. Exp. Toxicol. Pathol. 2008; 60(1): 51-7.

6. Sun JD, Henderson RF, Marshall TC, Cheng YS, Dutcher JS, Pickrell JA, Mauderly JL, Hahn FF, Banas DA, Seiler FA, Hobbs $\mathrm{CH}$. The inhalation toxicity of two commercial dyes: Solvent yellow 33 and solvent green 3 . Fund. Appl. Toxicol. 1987; 8(3): 358-71.

7. Borzelleca JF, Capen CC, Hallagan JB. Lifetime toxicity/carcinogenicity study of FD \& C Red No. 3 (erythrosine) in rats. Food Chem. Toxicol. 1987; 25(10): 723-33.

8. Ahmad A, Setapar SHM, Chuong CS, Khatoon A, Wani WA, Kumard R, Rafatullah M. Recent advances in new generation dye removal technologies: Novel search for approaches to reprocess wastewater. RSC Adv. 2015; 5: 30801-18.

9. Rafatullah M, Sulaiman O, Hashim R, Ahmad A. Adsorption of methylene blue on low-cost adsorbents: A review. J. Hazard. Mater. 2010; 177(1-3): 70-80.

10. Gupta VK, Suhas A. Application of low-cost adsorbents for dye removal - A review. J. Environ. Manag. 2009; 90(8):2313-42.

11. Vakili M, Rafatullah M, Salamatinia B, Abdullah AZ, Ibrahim MH, Tan KB, Gholami Z, Amouzgar P. Application of chitosan and its derivatives as adsorbents for dye removal from water and wastewater: A review. Carbohydrate Polymers. 2014; 113: 115-30.

12. Heibati B, Couto SR, Amrane A, Rafatullah M, Hawari A, Al-Ghouti MA. Uptake of reactive black 5 by pumice and walnut activated carbon: Chemistry and adsorption mechanisms. J. Ind. Eng. Chem. 2014; 20(5): 2939-47.

13. Moran C, Hall ME, Howell RC. Effects of sewage treatment on textile effluent. J. Soc. Dyers Colour. 1997;113(10):272-4.

14. Jain AK, Gupta VK, Bhatnagar A, Suhas. Utilization of industrial waste products as adsorbents for the removal of dyes. J. Hazard. Mater. 2003; 101(1): 31-42.

15. Khan MA, Govindasamy R, Siddiqui MR, Alshareef SA, Hakami AAH, Rafatullah M. Carbon based polymeric nanocomposites for dye adsorption : Synthesis, characterization, and application. Polymers. 2021;13(3): 419.

16. Shen K, Gondal MA. Removal of hazardous rhodamine dye from water by adsorption onto exhausted coffee ground. J. Saudi Chem Soc. 2017; 21(Suppl.1): S120-S127.

17. Escudero LB, Quintas PY, Wuilloud RG, Dotto GL. Biosorption of metals and metalloids. In: G. Crini, E. Lichtfouse (eds.), Green Adsorbents for Pollutant Removal. NY : Springer International Publishing, pp. 35-86.

18. Oyekanmi AA, Ahmad A, Hossain K, Rafatullah M. Statistical optimization for adsorption of rhodamine B dye from aqueous solutions. J. Mol. Liq. 2019; 281: 48-58.

19. Zhao B, Ren L, Du Y, Wang J. Eco-friendly separation layers based on waste peanut shell for gravity-driven waterin-oil emulsion separation. J. Clean. Prod. 2020; 255: 120184.

20. Ahmad A, Lokhat D, Rafatullah M, Khatoon A, Setapar SHM. Aloe vera biomass containing cellulosic moieties used as sustainable adsorbents for the removal of crystal violet dye from aqueous solution. Desalin. Water Treat. 2019; 170: 337-48.

21. Bhaumik R, Mondal NK, Das B, Roy P, Pal KC, Das C, Banerjee A, Datta JK. Eggshell powder as an adsorbent for removal of fluoride from aqueous solution: Equilibrium, kinetic and thermodynamic studies. J. Chem. 2012; 9(3): 1457-80.

22. Oyekanmi AA, Ahmad A, Hossain K, Rafatullah M. Adsorption of rhodamine B dye from aqueous solution onto acid treated banana peel: Response surface methodology, kinetics and isotherm studies. PloS One. 2019; 14(5): e0216878.

23. Boumchita S, Lahrichi A, Benjelloun Y, Lairini S, Nenov V, Zerrouq F. Application of peanut shell as a low-cost adsorbent for the removal of anionic dye from aqueous solutions. J. Mat. Environ. Sci. 2017; 8(7): 2353-64.

24. Al-Othman ZA, Ali R, Naushad M. Hexavalent chromium removal from aqueous medium by activated carbon prepared from peanut shell: Adsorption kinetics, equilibrium and thermodynamic studies. Chem. Eng. J. 2017; 184: 238-47.

25. Thomas B, German GS, Hande Y, Serge R, Luis DS. Best Available Techniques (BAT) Reference Document for Common Waste Water and Waste Gas Treatment/Management Systems in the Chemical Sector. Joint Research Center Science for Policy Report, Publications Office of the European Union. 2016.

26. Arunlertaree C, Kaewsomboon W, Kumsopa A, Pokethitiyook P, Panyawathanakit P. Removal of lead from battery manufacturing wastewater by egg shell. Songklanakarin J. Sci. Technol. 2007; 29(3): 857-68.

27. Massie BJ, Sanders TH, Dean LL. Removal of heavy metal contamination from peanut skin extracts by waste biomass adsorption. J. Food Process Eng. 2015; 38(6): 555-61. 
28. Suvarna SK, Layton C, Bancroft JD. Bancroft's Theory and Practice of Histological Techniques. Canada: Elsevier. 2013; 672p.

29. Holman WL. The use of decolorized acid fuchsin as an acid indicator in carbohydrate fermentation tests with some remarks on acid production by bacteria. J. Infect. Dis.1914; 15(1): 227-33.

30. Lillie RJ, Frobish LT, Steele NC, Graber G. Effect of dietary copper and tylosin and subsequent withdrawal on growth, hematology and tissue residues of growing-finishing pigs. J. Anim. Sci. 1977; 45(1): 100-7.

31. Mojsov KD, Andronikov D, Janevski A, Kuzelov A, Gaber S. The application of enzymes for the removal of dyes from textile effluents. Adv. Technol. 2016; 5(1): 81-6.

32. Xu W, Zhao Q, Wang R, Jiang Z, Zhang Z, Gao X, Ye Z. Optimization of organic pollutants removal from soil eluent by activated carbon derived from peanut shells using response surface methodology. Vacuum. 2017; 141: 307-15.

33. Garga D, Kumar S, Sharma K, Majumder CB. Application of waste peanut shells to form activated carbon and its utilization for the removal of Acid Yellow 36 from wastewater. Groundw. Sustain. Dev. 2019; 8: 512-9.

34. Regunton PCV, Sumalapao DEP, Villarante NR. Biosorption of methylene blue from aqueous solution by coconut (Cocos nucifera) shell- derived activated carbon-chitosan composite. Orient. J. Chem. 2018; 34(1): 115-24.

35. Salleh MAA, Mahmoud DK, Karim WA, Idris A. Cationic and anionic dye adsorption by agricultural solid wastes: A comprehensive review. Desalination 2011; 280(1-3): 1-13.

36. Sattar MS, Shakoor MB, Ali S, Rizwan M, Niazi NK, Jilani A. Comparative efficiency of peanut shell and peanut shell biochar for removal of arsenic from water. Environ. Sci. Pollut. 2019; 26: 18624-35.

37. Nadeem R, Manzoor Q, Iqbal M, Nisar J. Biosorption of $\mathrm{Pb}$ (II) onto immobilized and native Mangifera indica waste biomass. J. Ind. Eng. Chem. 2016; 35: 184-95.

38. Ullah I, Aziya R, Deem N, Lqbal M, Manzoor Q. Biosorption of chromium onto native and immobilized sugarcane bagasse waste biomass. Ecol. Eng. 2013; 60: 99-107.

39. Witek-Krowiak A, Szafran RG, Modelski S. Biosorption of heavy metals from aqueous solutions onto peanut shell as a low-cost biosorbent. Desalination 2019; 8(1-3): 512-9.

40. Shroff KA, Vaidya VK. Kinetics and equilibrium studies on biosorption of nickel from aqueous solution by dead fungal biomass of Mucor hiemalis. Chem. Eng. J. 2011; 171(3): 1234-45.

41. Villarreal IAA, Montoya LAR, Montoya VH, Petriciolet AB, Morán MAM, López EMR. Sorption mechanism of anionic dyes on pecan nut shells (Carya illinoinensis) using batch and continuous systems. Ind. Crops Prod. 2013; 48: 89-97.

42. Gama BMV, Nascimento GE, Silva Sale DC, Diaz JMR, Menezes Barbosa CMB, Bezerra Duarte MMM. Mono and binary component adsorption of phenol and cadmium using adsorbent derived from peanut shells. J. Clean. Prod. 2018; 201: 219-28.

43. Tahir N, Bhatti HN, Lqbal M, Noreen S. Biopolymers composites with peanut hull waste biomass and application for Crystal Violet adsorption. Int. J. Biol. Macromol. 2017; 94: 210-20.

(C) 2021 by the authors. Submitted for possible open access publication under the terms and conditions of the Creative Commons Attribution (CC BY NC) license (https://creativecommons.org/licenses/by-nc/4.0/). 